\title{
Efficacy of Potassium Permanganate Impregnated into Alumina Beads to Reduce Atmospheric Ethylene
}

\author{
R.B.H. Wills and M.A. Warton \\ School of Applied Sciences, University of Newcastle, P.O. Box 127 Ourimbah NSW 2258 Australia
}

ADDITIONAL INDEX wORDs. ethylene absorption, postharvest horticulture, humidity

\begin{abstract}
A systematic study was conducted on the ability of potassium permanganate absorbent to remove low levels of ethylene from the atmosphere. Absorption of potassium permanganate onto alumina beads by dipping in a saturated solution was maximal at $2 \mathrm{~g} / 100 \mathrm{~g}$ after 2 hours at $20^{\circ} \mathrm{C}$ and $4 \mathrm{~g} / 100 \mathrm{~g}$ after 1 hour at $65^{\circ} \mathrm{C}$. Commercial alumina-based absorbents were found to contain potassium permanganate at 2.7 to $6.0 \mathrm{~g} / 100 \mathrm{~g}$ suggesting many are prepared at elevated temperature. Trials in a closed system at $20{ }^{\circ} \mathrm{C}$ and $60 \%$ to $70 \% \mathrm{RH}$ with alumina beads containing potassium permanganate at $4 \mathrm{~g} / 100 \mathrm{~g}$ showed a logarithmic decrease in ethylene concentration with $90 \%$ of the ethylene removed after 2.5 to 3.0 hours. Relative humidity (RH) had a marked inverse effect on ethylene absorption with reactivity at $100 \% \mathrm{RH}$ calculated to be $15 \%$ of that at $0 \% \mathrm{RH}$. Performance of potassium permanganate where ethylene was continually generated by a continuous flow of ethylene at $14 \mu \mathrm{L} \cdot \mathbf{h}^{-1}$ through the container showed a steady state was attained within 1 hour and maintained for 24 hours. Ethylene removal increased linearly with bead weight and ranged from $30 \%$ with $1 \mathrm{~g}$ to $90 \%$ with $50 \mathrm{~g}$. Examination over 20 days showed a continuing decrease in rate of ethylene removal which after 14 days had declined to $10 \%$ of incoming ethylene although $44 \%$ of the original level of potassium permanganate still remained in the beads. Calculations based on known endogenous ethylene production rates suggest that at $20{ }^{\circ} \mathrm{C}$ and $90 \% \mathrm{RH}$, use of a potassium permanganate-alumina absorbent would be beneficial with produce having a low level of ethylene generation. Suitability for larger packages of produce generating higher ethylene levels is questionable as $>1 \mathrm{~kg}$ of absorbent may be required.
\end{abstract}

Reducing the level of ethylene in the atmosphere around harvested horticultural commodities has been well recognized to delay the development of senescence of non-climacteric produce and the onset of ripening in climacteric fruits. A concentration of ethylene in air of $0.1 \mu \mathrm{L}^{\cdot} \mathrm{L}^{-1}$ is often quoted as the threshold level for physiological activity (Kader, 1985). However, from studies on bananas by Peacock (1972) and recently on a wide range of fruit and vegetables by Wills et al. (1999; 2001) any level of ethylene is considered to have a deleterious effect on produce with decrease in postharvest life linearly related to increasing $\log _{10}$ ethylene concentration. Many intervention strategies have been developed for protecting postharvest commodities from the detrimental effects of ethylene.

Potassium permanganate is a stable purple solid that is a strong oxidizing agent and readily oxidizes ethylene. The ability of potassium permanganate to reduce ethylene concentration in the atmosphere around horticultural produce was first demonstrated by Forsyth et al. (1967) on apples. The reduction in ethylene affected by addition of potassium permanganate was subsequently found to delay the ripening of many climacteric fruits such as banana (Scott et al., 1970), kiwifruit (Scott et al., 1984), mango (Esguerra et al., 1978) and avocado (Hatton and Reeder, 1972). Fewer studies have been conducted with non-climacteric produce but potassium permanganate has been found to extend postharvest life by retarding loss of green color and microbial wastage of lemon (Wild et al., 1976) and lettuce (Kim and Wills, 1995) and inhibiting rotting of strawberry (Wills and Kim, 1995).

For potassium permanganate to be effective in oxidizing quite small concentrations of ethylene from the atmosphere around produce where natural convection and diffusion are the only driving forces giving contact between ethylene and the oxidant, the potassium permanganate needs to have a high surface area exposed to the atmosphere. This has been achieved by the absorption of potassium permanganate onto porous inert minerals such

Received for publication 29 July 2003. Accepted for publication 12 Dec. 2003. as celite (Forsyth et al., 1967), vermiculite (Scott et al., 1970), alumina (Jayamaran and Raju, 1992), zeolite (Oh et al., 1996) and clay (Picon et al., 1993). A range of commercial potassium permanganate products is now available with a common carrier being alumina beads (e.g., Purafil (Purafil, Doraville Ga.), Circul-Aire (Circul-Aire, Montreal), Ethysorb (Molecular Products, Thaxted, Essex) and Bloomfresh (Ausdel, Cheltenham, Victoria)). However, these products are mainly used to remove organic contaminants from the atmosphere in ducted air conditioning systems and there has not been any meaningful commercial use with horticultural produce.

Most published studies using a laboratory prepared or a commercial potassium permanganate product have evaluated the effect of single weight of product on a single produce with most papers not reporting the concentration of potassium permanganate in the product used and often not determining the effect on ethylene concentration. The most comprehensive studies on potassium permanganate were firstly by Lidster et al. (1985) who found that alumina pellets retained a much greater amount of potassium permanganate than expanded glass beads, the efficiency of each product to reduce ethylene increased with temperature but contrasting effects were obtained with increasing relative humidity (RH). Secondly, Kavanagh and Wade (1987) studied 21 carrier materials and found large variation among carriers with those of lower bulk density and a higher capacity to absorb potassium permanganate being more efficient in reducing ethylene levels.

It is considered that the lack of systematic quantitative studies on the ability of potassium permanganate to absorb ethylene has hindered commercial use with horticultural commodities. The lack of such studies has meant that no recommendations have been published for the amount of potassium permanganate needed to achieve either a specified decrease in ethylene concentration or an increase in postharvest life of a commodity. Further, it is noted that the labels of commercial products do not indicate the concentration of potassium permanganate although Abeles et al. (1992) report that it is typically 4 to $6 \mathrm{~g} / 100 \mathrm{~g}$. This paper quantitatively examined 
the ability of alumina beads to absorb potassium permanganate and the effect of impregnated beads on the absorption of ethylene under a range of environmental conditions.

\section{Materials and Methods}

Preparation and ANAlysis OF POTASSIUM PERManganate ProdUCTS. A range of laboratory prepared products was generated by dipping activated alumina beads $(0.5 \mathrm{~cm}$ in diameter) (Sigma, St Louis Mo.) in a saturated solution of potassium permanganate (Grade 2 FSE, Homebush, Sydney) (6.4 g/100 mL (Lide, 1994) at $20{ }^{\circ} \mathrm{C}$ for 1 ) varying times between $3 \mathrm{~min}$ to $4 \mathrm{~h}$, and 2) for 3 min, allowing to dry in air for $30 \mathrm{~min}$ and repeating the dipping and drying process for up to four times. The final drying of the impregnated beads was achieved by allowing beads to dry in ambient air at $20^{\circ} \mathrm{C}$ for $16 \mathrm{~h}$. The effect of dipping temperature was examined by dipping in a solution containing potassium permanganate at $10 \mathrm{~g} / 100 \mathrm{~mL}$ at 20,65 , and $90{ }^{\circ} \mathrm{C}$ for 1,3 , and $5 \mathrm{~h}$ at each temperature. A constant concentration of potassium permanganate was used even though at $20^{\circ} \mathrm{C}$ some of the potassium permanganate was only in suspension while at the higher temperatures it was all dissolved (Lide, 1994).

The color of potassium permanganate impregnated beads was assessed visually and with a color meter (Minolta Chroma Meter CR-300, Osaka) using Hunterlab L (lightness), a (green-red) and b (blue-yellow) color coordinate values. Whole or powdered beads were placed onto a small dish and the color values were recorded as the mean values of 10 measurements. From the L, $\mathrm{a}$ and $\mathrm{b}$ values, the color characteristics, chroma $(\mathrm{C})=\sqrt{ }\left(\mathrm{a}^{2}+\right.$ $\left.b^{2}\right)$; and total color difference $(\Delta E)=\sqrt{ }\left[\left(L-L_{o}\right)^{2}+\left(a-a_{o}\right)^{2}+(b\right.$ $\left.-\mathrm{b}_{\mathrm{o}}\right)^{2}$, were calculated.

The concentration of potassium permanganate was determined by grinding a sample of beads $(2 \mathrm{~g})$ with a mortar and pestle. A sample of powder $(0.2 \mathrm{~g})$ was placed in water made up to 100 $\mathrm{mL}$ in a foil covered volumetric flask, which was shaken for 2 min then centrifuged (J2-MC; Beckman, Palo Alto Calif.) for $45 \mathrm{~min}$ at 2,000 $\mathrm{g}_{\mathrm{n}}$. The solution was placed into a cuvette and the absorbance at $528 \mathrm{~nm}$ determined with a spectrophotometer (Cary Win UV; Varian, Mulgrave, Victoria). The absorbance was quantified by comparison with standard solutions of potassium permanganate. The concentration of potassium permanganate in some commercial products was also determined.

EFFICIENCY OF ETHYLENE ABSORPTION. The ability of alumina beads impregnated with potassium permanganate at $4 \mathrm{~g} / 100 \mathrm{~g}$ to remove ethylene from the surrounding atmosphere was determined using a closed system with an initial ethylene loading and a flow system with a constant ethylene concentration in the passing air stream.

In the closed system, impregnated alumina beads ( $1 \mathrm{~g})$ were placed as a single layer in a sealed 4-L container at ambient relative humidity $(60 \%$ to $70 \% \mathrm{RH})$ at $20{ }^{\circ} \mathrm{C}$ and 80 or $150 \mu \mathrm{L}$ of a gas containing $98 \%$ ethylene (BOC Gases, Sydney) was added. At regular intervals, a sample $(1 \mathrm{~mL})$ of the atmosphere was collected in a syringe and the ethylene concentration was determined by flame ionization gas chromatography (series 580; Gow-Mac, Bridgewater, N.J.) fitted with a stainless steel column $(180 \times 0.3$ $\mathrm{cm}$ ) packed with activated alumina (80 to 100 mesh) (Alltech, Sydney) and operating conditions of column temperature $110^{\circ} \mathrm{C}$, injector and detector temperature $150^{\circ} \mathrm{C}$, nitrogen carrier gas flow velocity $30 \mathrm{~mL} \cdot \mathrm{min}^{-1}$, hydrogen flow rate $30 \mathrm{~mL} \cdot \mathrm{min}^{-1}$ and air flow rate $300 \mathrm{~mL} \cdot \mathrm{min}^{-1}$. Ethylene was quantified by comparison of the peak height with that obtained for a standard gas mixture containing $0.16 \pm 0.05 \mu \mathrm{L} \cdot \mathrm{L}^{-1}$ (BOC Gases, Sydney). Ethylene was monitored until the concentration had declined to $0.005 \mu \mathrm{L} \cdot \mathrm{L}^{-1}$, the limit of detection of the analytical method.

The effect of $\mathrm{RH}$ on absorption efficiency at $20{ }^{\circ} \mathrm{C}$ was determined by placing in the sealed container with potassium permanganate impregnated alumina beads, a dish containing a saturated solution of potassium hydroxide, sodium dichromate, barium chloride, potassium acetate and potassium carbonate to generate air of about $25 \%, 35 \%, 50 \%, 70 \%$, and $90 \% \mathrm{RH}$, respectively (Dean 1995). The system was left to equilibrate for $16 \mathrm{~h}$ when the RH was measured using an RH probe (MultiMeterMate; Vaisala, Helsinki). Ethylene $(150 \mu \mathrm{L})$ was then injected into the container and its concentration monitored every 10 min until $90 \%$ of the ethylene had been removed.

In the flow-through system, air at $70 \%$ RH containing $0.7 \mu \mathrm{L} \cdot \mathrm{L}^{-1}$ ethylene was passed through the $4-\mathrm{L}$ container at $20 \mathrm{~L} \cdot \mathrm{h}^{-1}$. The weight of beads in the container was varied from 1 to $50 \mathrm{~g}$, while maintaining a single layer of beads to maximise exposure to the atmosphere. The level of ethylene entering and leaving the container was monitored over $24 \mathrm{~h}$. The longevity of the impregnated beads to absorb ethylene was determined on $1 \mathrm{~g}$ of beads, which were ventilated until the rate of ethylene absorption was greatly reduced. The total amount of ethylene absorbed and the proportion of potassium permanganate oxidized were calculated.

The change in potassium permanganate content of alumina beads and bead color during exposure to ethylene was determined. Freshly prepared beads were placed in the flow-through system and the visual change in bead color was monitored on a 5 to 1 scale where $5=100 \%$ purple, $4=75 \%$ purple, $3=50 \%$ purple, $2=25 \%$ purple, and $1=100 \%$ brown. A sample of beads was removed at various visual color stages and Hunterlab color measurements were made on the intact beads and ground bead powder. The amount of potassium permanganate remaining in each bead sample was also determined.

Table 1. Potassium permanganate uptake and color of alumina beads dipped in saturated potassium permanganate solution at $20^{\circ} \mathrm{C}$ for various times. Values are the mean of three replications.

\begin{tabular}{lccccc}
\hline & \multirow{2}{*}{$\begin{array}{c}\mathrm{KMnO}_{4} \\
\text { Dip }\end{array}$} & $\begin{array}{c}\text { uptake } \\
\text { time }\end{array}$ & & \multicolumn{4}{c}{ Head color } \\
\cline { 2 - 6 } & $(\mathrm{g} / 100 \mathrm{~g})$ & Visual & $\mathrm{L}$ & $\mathrm{a}$ & $\mathrm{b}$ \\
\hline 0 & $0 \mathrm{a}^{\mathrm{z}}$ & White & $59 \mathrm{a}$ & $5 \mathrm{a}$ & $18 \mathrm{a}$ \\
$3 \mathrm{~min}$ & $0.5 \mathrm{~b}$ & Pale pink & $45 \mathrm{~b}$ & $26 \mathrm{~b}$ & $4 \mathrm{~b}$ \\
$1 \mathrm{~h}$ & $1.5 \mathrm{c}$ & Dark pink & $38 \mathrm{c}$ & $30 \mathrm{~b}$ & $-5 \mathrm{c}$ \\
$2 \mathrm{~h}$ & $1.9 \mathrm{~d}$ & Purple & $35 \mathrm{~d}$ & $30 \mathrm{~b}$ & $-5 \mathrm{c}$ \\
$3 \mathrm{~h}$ & $2.0 \mathrm{~d}$ & Purple & $35 \mathrm{~d}$ & $30 \mathrm{~b}$ & $-10 \mathrm{~d}$ \\
$4 \mathrm{~h}$ & $2.0 \mathrm{~d}$ & Purple & $34 \mathrm{~d}$ & $28 \mathrm{~b}$ & $-8 \mathrm{~d}$ \\
\hline
\end{tabular}

${ }^{\mathrm{z}}$ Mean separation by $\mathrm{LSD}_{0.05}$.

Table 2. Potassium permanganate uptake and color of alumina beads following repeated dipping for $3 \mathrm{~min}$ in saturated potassium permanganate solution at $20^{\circ} \mathrm{C}$ and $30 \mathrm{~min}$ between dips. Values are the mean of three replications.

\begin{tabular}{|c|c|c|c|c|c|}
\hline \multirow{3}{*}{$\begin{array}{l}\text { Dip } \\
\text { no. }\end{array}$} & \multirow{3}{*}{$\begin{array}{c}\mathrm{KMnO}_{4} \\
\text { uptake } \\
(\mathrm{g} / 100 \mathrm{~g})\end{array}$} & \multicolumn{4}{|c|}{ Bead color } \\
\hline & & \multirow[b]{2}{*}{ Visual } & \multicolumn{3}{|c|}{ Hunterlab } \\
\hline & & & $\mathrm{L}$ & $\mathrm{a}$ & $\mathrm{b}$ \\
\hline$\overline{0}$ & $0 \mathrm{a}^{\mathrm{z}}$ & White & $59 \mathrm{a}$ & $5 \mathrm{a}$ & $18 \mathrm{a}$ \\
\hline 1 & $0.5 \mathrm{~b}$ & Pale pink & $45 \mathrm{~b}$ & $26 \mathrm{~b}$ & $4 \mathrm{~b}$ \\
\hline 2 & $1.3 \mathrm{c}$ & Dark pink & $40 \mathrm{bc}$ & $29 \mathrm{c}$ & $-0 \mathrm{c}$ \\
\hline 3 & $1.8 \mathrm{~d}$ & Purple & $35 \mathrm{c}$ & $26 \mathrm{~b}$ & $-1 \mathrm{c}$ \\
\hline 4 & $2.1 \mathrm{~d}$ & Purple & $33 \mathrm{c}$ & $26 \mathrm{~b}$ & $-1 \mathrm{~d}$ \\
\hline
\end{tabular}

zMean separation by $\mathrm{LSD}_{0.05}$. 
Table 3. Potassium permanganate uptake and color of alumina beads following dipping in $10 \mathrm{~g} / 100 \mathrm{~mL}$ potassium permanganate solution at different temperatures for various times. Values are the mean of three replications.

\begin{tabular}{|c|c|c|c|c|c|c|}
\hline \multirow{3}{*}{$\begin{array}{l}\text { Temp } \\
\left({ }^{\circ} \mathrm{C}\right)\end{array}$} & \multirow{3}{*}{$\begin{array}{l}\text { Dip } \\
\text { time } \\
(\mathrm{h})\end{array}$} & \multirow{3}{*}{$\begin{array}{c}\mathrm{KMnO}_{4} \\
\text { uptake } \\
(\mathrm{g} / 100 \mathrm{~g})\end{array}$} & \multicolumn{4}{|c|}{ Bead color } \\
\hline & & & \multirow[b]{2}{*}{ Visual } & \multicolumn{3}{|c|}{ Hunterlab } \\
\hline & & & & $\mathrm{L}$ & $\mathrm{a}$ & $\mathrm{b}$ \\
\hline \multirow[t]{3}{*}{20} & 1 & $2.3 \mathrm{a}^{\mathrm{z}}$ & Purple & $33 \mathrm{a}$ & $29 \mathrm{a}$ & $-10 \mathrm{a}$ \\
\hline & 3 & $2.5 \mathrm{a}$ & Purple, few surface crystals & $29 \mathrm{~b}$ & $27 \mathrm{~b}$ & $-10 \mathrm{a}$ \\
\hline & 5 & $2.7 \mathrm{a}$ & Purple, few surface crystals & $33 \mathrm{a}$ & 29 a & $-11 \mathrm{a}$ \\
\hline \multirow[t]{3}{*}{65} & 1 & $4.0 \mathrm{~b}$ & Dark purple & $30 \mathrm{~b}$ & $25 \mathrm{c}$ & $-9 \mathrm{a}$ \\
\hline & 3 & $4.8 \mathrm{c}$ & Dark purple, surface crystals & $32 \mathrm{a}$ & $25 \mathrm{c}$ & $-9 \mathrm{a}$ \\
\hline & 5 & $4.7 \mathrm{c}$ & Dark purple, surface crystals & $26 \mathrm{c}$ & $20 \mathrm{~d}$ & $-6 b$ \\
\hline \multirow[t]{3}{*}{90} & 1 & $6.2 \mathrm{e}$ & Many surface crystals & $27 \mathrm{bc}$ & $16 \mathrm{e}$ & $-3 c$ \\
\hline & 3 & $5.4 \mathrm{~d}$ & Brown & $24 \mathrm{~d}$ & $7 \mathrm{f}$ & $8 \mathrm{~d}$ \\
\hline & 5 & $3.4 \mathrm{~b}$ & Brown & $25 \mathrm{~cd}$ & $7 \mathrm{f}$ & $10 \mathrm{e}$ \\
\hline
\end{tabular}

${ }^{2}$ Mean separation by $\operatorname{LSD}_{0.05}$.

Table 4. Relationship $(\mathrm{y}=\mathrm{ax}+\mathrm{b})$ between potassium permanganate content of alumina beads (x) and surface color measurement (y) as represented by Hunterlab parameters of chroma (C) and total color difference $(\Delta \mathrm{E})$.

\begin{tabular}{lcccc}
\hline & $\mathrm{C}$ & \multicolumn{3}{c}{$\Delta \mathrm{E}$} \\
\hline Expt. & Regression & $P$ & Regression & $P$ \\
\hline 1 & $\mathrm{y}=5 \mathrm{x}+21$ & $<0.01$ & - & NS \\
2 & --- & NS & $\mathrm{y}=6 \mathrm{x}+26$ & $<0.05$ \\
3 & $\mathrm{y}=-4 \mathrm{x}+38$ & $<0.05$ & - & NS \\
\hline
\end{tabular}

Ns Nonsignificant at $P=0.05$.

Table 5. Relationship $(y=a x+b)$ between $\log _{10}$ ethylene concentration $\left(\mathrm{y}, \mu \mathrm{L} \cdot \mathrm{L}^{-1}\right)$ and time $(\mathrm{x}, \mathrm{h})$ exposed to potassium permanganate impregnated alumina beads in an atmosphere of varying relative humidity that initially contained $37.5 \mu \mathrm{L} \cdot \mathrm{L}^{-1}$ ethylene. Each equation was derived from three replicate runs.

\begin{tabular}{lccc}
\hline $\begin{array}{l}\text { Relative } \\
\text { humidity }(\%)\end{array}$ & Regression & $P$ & $\begin{array}{c}\text { Time to remove } \\
90 \% \text { ethylene }(\mathrm{h})\end{array}$ \\
\hline 25 & $\mathrm{y}=-0.62 \mathrm{x}+1.56$ & $<0.001$ & $1.6 \mathrm{a}^{\mathrm{z}}$ \\
35 & $\mathrm{y}=-0.50 \mathrm{x}+1.59$ & $<0.001$ & $2.0 \mathrm{a}$ \\
50 & $\mathrm{y}=-0.36 \mathrm{x}+1.61$ & $<0.001$ & $2.9 \mathrm{~b}$ \\
70 & $\mathrm{y}=-0.29 \mathrm{x}+1.59$ & $<0.001$ & $3.5 \mathrm{~b}$ \\
90 & $\mathrm{y}=-0.18 \mathrm{x}+1.57$ & $<0.001$ & $5.4 \mathrm{c}$ \\
\hline
\end{tabular}

${ }^{\mathrm{z}}$ Mean separation by $\mathrm{LSD}_{0.05}$.

\section{Results}

UPTAKE OF POTASSIUM PERMANGANATE BY ALUMINA BEADS. The concentration of potassium permanganate and external color of alumina beads dipped in a saturated solution of potassium permanganate $(6.4 \mathrm{~g} / 100 \mathrm{~mL})$ for different periods and left to dry overnight at $20{ }^{\circ} \mathrm{C}$ are presented in Table 1 . The uptake of potassium permanganate in the beads increased with increasing dip time up to $2 \mathrm{~h}$ when a concentration of about $2 \mathrm{~g} / 100 \mathrm{~g}$ was achieved. Repeated dipping of beads for $3 \mathrm{~min}$ in a saturated solution of potassium permanganate followed by air drying for 30 min (Table 2) showed that as the number of dips increased, the concentration of potassium permanganate increased up to a level of about $2 \mathrm{~g} / 100 \mathrm{~g}$.

The data in Table 3 show that incorporation of potassium permanganate into beads by dipping in a solution containing 10 $\mathrm{g} / 100 \mathrm{~mL}$ of potassium permanganate for $1 \mathrm{~h}$ at different solution temperatures increased from $\approx 2 \mathrm{~g} / 100 \mathrm{~g}$ at $20{ }^{\circ} \mathrm{C}$ to $4 \mathrm{~g} / 100$ g at $65{ }^{\circ} \mathrm{C}$ and $6 \mathrm{~g} / 100 \mathrm{~g}$ at $90{ }^{\circ} \mathrm{C}$, although at $90{ }^{\circ} \mathrm{C}$ much of the additional potassium permanganate was probably crystalline material on the bead surface. There was probably also some crystalline material on the surface of the beads dipped at $20^{\circ} \mathrm{C}$ as the potassium permanganate solution was supersaturated at this temperature, but was not sufficient to be observed. Longer dipping times of 3 and $5 \mathrm{~h}$ produced a relatively small increase in incorporation of potassium permanganate at 20 and $65^{\circ} \mathrm{C}$, which was probably due to surface deposition of crystals but there was a decrease at $90{ }^{\circ} \mathrm{C}$ with the beads developing a brown color typical of oxidized potassium permanganate.

In the three experiments, the increase in potassium permanganate was generally associated with an increase in the intensity of visual purple color and a decrease in Hunterlab L and $b$ parameters on the surface of the beads (Tables 1-3). Linear regressions of the relationship between potassium permanganate content $(\mathrm{x})$ and chroma $(C)$ and total color difference $(\Delta E)(y)$ were calculated for the data in each experiment but the data in Table 4 show that neither color parameter gave a consistent relationship with potassium permanganate content across the three experiments.

The concentration of potassium permanganate was determined in four commercial products that used alumina as the carrier. Levels varied widely and in increasing order were $2.70 \pm 0.05$ $\mathrm{g} / 100 \mathrm{~g}$ in Ethysorb, $4.07 \pm 0.04$ in CirculAire, $4.10 \pm 0.08$ in Purafil and $5.97 \pm 1.43$ in Bloomfresh (values are the mean of three 2-g samples).

REMOVAL OF ETHYLENE FROM THE ATMOSPHERE. Alumina beads ( $1 \mathrm{~g}$ ) impregnated with potassium permanganate at $4 \mathrm{~g} / 100 \mathrm{~g}$ were placed into a sealed container at ambient relative humidity $(60 \%$ to $70 \% \mathrm{RH})$ at $20{ }^{\circ} \mathrm{C}$ containing ethylene at 37.5 and $20 \mu \mathrm{L} \cdot \mathrm{L}^{-1}$. The ethylene concentration in the atmosphere was found to decline over time to $<0.005 \mu \mathrm{L} \cdot \mathrm{L}^{-1}$. The relationship between ethylene concentration and time followed a linear regression of the $\log _{10}$ ethylene $\left(\mathrm{y}, \mu \mathrm{L} \cdot \mathrm{L}^{-1}\right)$ and time $(\mathrm{x}, \mathrm{min})$ of $\mathrm{y}=-0.006 \mathrm{x}+1.71(P$ $<001)$, and $y=-0.008 x+1.44(P<0.001)$ for the 37.5 and 20 $\mu \mathrm{L} \cdot \mathrm{L}^{-1}$ initial concentrations, respectively. From the respective equations the calculated time to remove $90 \%$ of the ethylene from an initial atmosphere of 37.5 and $20 \mu \mathrm{L} \cdot \mathrm{L}^{-1}$ ethylene was 3.0 and $2.5 \mathrm{~h}$, respectively.

The reduction in an initial ethylene concentration of 37.5 $\mu \mathrm{L} \cdot \mathrm{L}^{-1}$ in air of $25 \%$ to $90 \% \mathrm{RH}$ in the presence of potassium permanganate impregnated beads was determined over time. Regression analysis of the change in ethylene with time showed that at each RH level there was a linear decrease in $\log _{10}$ ethylene concentration with time but there was a significant difference in the slopes of the equations; that is, the rate of loss of ethylene (Table 5). Table 5 also shows that the calculated time to remove $90 \%$ of the initial ethylene concentration significantly increased with increasing RH, and Fig. 1 shows an inverse linear relation- 


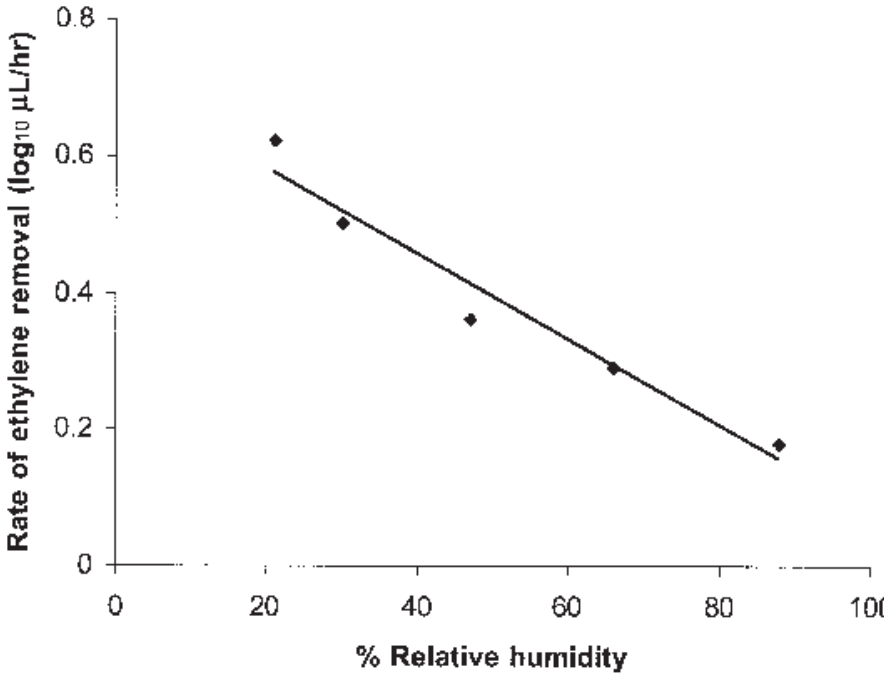

Fig. 1. Relationship between relative humidity and $\log _{10}$ rate of ethylene removal by potassium permanganate. Values are the mean of three replications.

Table 6. Effect of amount of potassium permanganate impregnated beads on the equilibrium ethylene removal from the flowing air stream with ethylene entering at $0.7 \mu \mathrm{L} \cdot \mathrm{L}^{-1}$. Values are the mean of four replications.

\begin{tabular}{lcc}
\hline $\begin{array}{l}\text { Bead wt } \\
(\mathrm{g})\end{array}$ & $\begin{array}{c}\text { Ethylene in exit air } \\
\left(\mu \mathrm{L} \cdot \mathrm{L}^{-1}\right)\end{array}$ & $\begin{array}{c}\text { Ethylene removed } \\
(\%)\end{array}$ \\
\hline 1 & $0.50 \mathrm{a}^{\mathrm{z}}$ & 29 \\
5 & $0.27 \mathrm{~b}$ & 61 \\
10 & $0.16 \mathrm{c}$ & 77 \\
50 & $0,06 \mathrm{~d}$ & 91 \\
\hline
\end{tabular}

${ }^{\mathrm{z}}$ Mean separation by $\mathrm{LSD}_{0.05}$

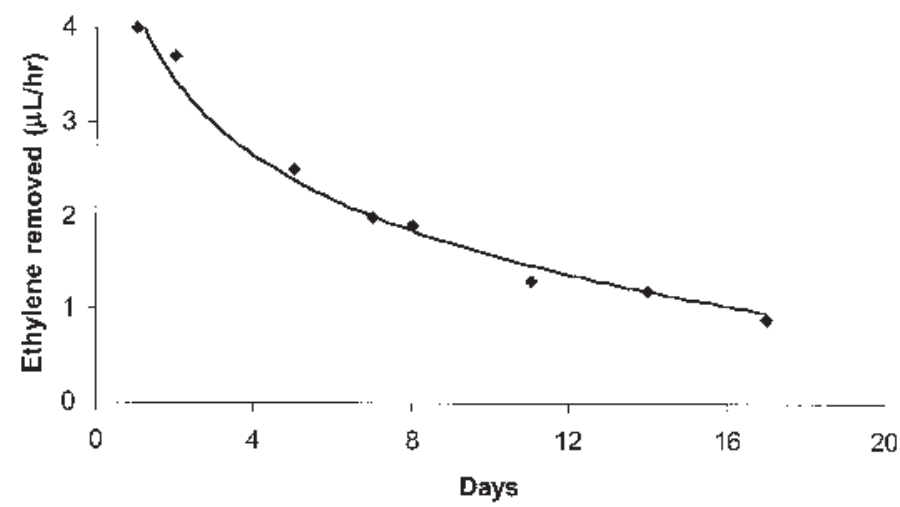

Fig. 2. Change in efficiency of removal over time of ethylene added to a flowing air stream at $14 \mu \mathrm{L} \cdot \mathrm{h}^{-1}$ by potassium permanganate impregnated alumina beads $(1 \mathrm{~g})$. Values are the mean of three replications.

ship between the $\log _{10}$ rate of loss of ethylene (y) and $\mathrm{RH}(\mathrm{x})(\mathrm{y}=$ $-0.0064 \mathrm{x}+0.72 ; P<0.001)$. Extrapolating the relationship shown in Fig. 1 back to $0 \% \mathrm{RH}$, which can be considered to give the rate of reaction without any interference from water vapor, represents the maximum rate or $100 \%$ efficiency. Extrapolating to $100 \% \mathrm{RH}$, an atmosphere often found around horticultural produce, is where maximum interference from water vapor occurs. Comparison of the reaction rates gives an atmosphere of $100 \%$ RH having only $15 \%$ of the efficiency obtained with dry air.

To understand how potassium permanganate would perform in the presence of horticultural crops where ethylene is continu- ally being produced, performance of the potassium permanganate impregnated beads was evaluated in a flow-through system at $70 \%$ $\mathrm{RH}$. Ethylene at $0.7 \mu \mathrm{L} \cdot \mathrm{L}^{-1}$ was passed through containers holding $1,5,10$, or $50 \mathrm{~g}$ of beads at $20 \mathrm{~L} \cdot \mathrm{h}^{-1}$, that is the equivalent of ethylene entering the chamber at $14 \mu \mathrm{L} \cdot \mathrm{h}^{-1}$. The difference in ethylene concentration between air entering and leaving the container was measured over time. For each weight of bead, the concentration of ethylene in the outlet air achieved a relatively steady state within $1 \mathrm{~h}$ and was maintained over the 24 -h period of the trial. The data in Table 6 show that the proportion of ethylene removed increased as the weight of bead in the container increased and followed a linear regression of $y=24 x+34(P<0.001)$ where $y=\operatorname{arc} \sin$ transformation of percent ethylene removed, and $\mathrm{x}=\log _{10} \mathrm{~g}$ bead weight.

The ability of the potassium permanganate impregnated beads to remove ethylene over an extended period was examined by holding $1 \mathrm{~g}$ of beads in a ventilated container and the ethylene concentration determined in the exiting air over $14 \mathrm{~d}$. The data in Fig. 2 show that the rate of ethylene removal decreased over time. Analyzing the data as $\log _{10}$ rate of removal, generated a linear regression, $y$ $=-0.0017 x+0.59,(P<0.001)$. If the useful life, or longevity, of the beads is defined as the time that they will continue to absorb $>10 \%$ of the incoming ethylene, then the beads have a longevity of about $14 \mathrm{~d}$. The total amount of ethylene removed over the 14 $\mathrm{d}$ was calculated from the area under the curve to be $0.76 \mathrm{~mL}$. The amount of potassium permanganate remaining in the beads after $14 \mathrm{~d}$ was determined as $0.018 \mathrm{~g} \cdot \mathrm{g}^{-1}$ of beads. Comparison with the amount of potassium permanganate in fresh beads showed that $44 \%$ of the original potassium permanganate was still present.

RELATIONSHIP BETWEEN COLOR CHANGE AND LOSS OF POTASSIUM PERMANGANATE. The external color of intact potassium permanganate impregnated beads $(4 \mathrm{~g} / 100 \mathrm{~g})$ during exposure to ethylene was observed to gradually change color from purple (score $=5$ ) to brown (score $=1$ ). As would be expected, the visual color score was found to be highly significantly correlated with Hunterlab color parameters for the intact bead with a decrease in visual color score associated with an increase in $\mathrm{b}, \mathrm{L}$ and $\Delta \mathrm{E}$ a decrease in a and $\mathrm{C}$ values (Table 7). The data in Table 8 show that only a small amount of potassium permanganate has degraded when the external bead color has changed to almost $100 \%$ brown (score $=1.5$ ) and $70 \%$ was still present when the beads were $100 \%$ brown.

Grinding the beads to a powder and conducting the same color measurements showed firstly, that there was the same strong correlation between the change in visual color and changes in Hunterlab color parameters as seen with intact beads (Table 7). However, in contrast to intact beads, the data in Table 8 show that the change in visual color score from purple to brown (y) across the color score range was associated with a decline in potassium permanganate content of the powder $(\mathrm{x})$ and was found to follow a highly significant linear regression, $\mathrm{y}=0.7 \mathrm{x}-0.2(P<0.001)$. Thus, the visual color of ground beads, unlike intact beads, was a good indicator of the amount of remaining (or used) potassium permanganate. Instrumental color measurements of intact beads and bead powder showed similar trends of an increase in $\mathrm{b}, \mathrm{L}$ and $\Delta \mathrm{E}$ a decrease in a and $\mathrm{C}$ values with potassium permanganate content but there was a much stronger correlation for bead powder (Table 9).

\section{Discussion}

Despite many published studies on the postharvest use of potassium permanganate absorbents to remove ethylene, few report the potassium permanganate content of the absorbents used. This would 
Table 7. Relationship $(y=a x+b)$ between Hunterlab color parameters (y) and visual color score (x) of intact and powdered alumina beads impregnated with potassium permanganate during exposure to ethylene at $14 \mu \mathrm{L} \cdot \mathrm{h}^{-1}$. Each regression was calculated from 15 pairs of values.

\begin{tabular}{lccccc}
\hline Hunterlab & \multicolumn{2}{c}{ Intact bead } & & \multicolumn{2}{c}{ Powdered bead } \\
\cline { 2 - 3 } \cline { 5 - 6 } parameter & Regression & $P$ & & Regression & $P$ \\
\hline $\mathbf{L}$ & $\mathrm{y}=-1.4 \mathrm{x}+34$ & $<0.001$ & $\mathrm{y}=-2.4 \mathrm{x}+57$ & $<0.001$ \\
$\mathbf{a}$ & $\mathrm{y}=4.7 \mathrm{x}+1.3$ & $<0.001$ & & $\mathrm{y}=7.8 \mathrm{x}-2.0$ & $<0.001$ \\
$\mathbf{b}$ & $\mathrm{y}=-4.0 \mathrm{x}+19$ & $<0.001$ & $\mathrm{y}=-8.8 \mathrm{x}+33$ & $<0.001$ \\
$\mathbf{C}$ & $\mathrm{y}=1.8 \mathrm{x}+14$ & $<0.001$ & & $\mathrm{y}=5.3 \mathrm{x}+11$ & $<0.001$ \\
$\Delta \mathbf{E}$ & $\mathrm{y}=-5.9 \mathrm{x}+30$ & $<0.001$ & $\mathrm{y}=-12 \mathrm{x}+67$ & $<0.001$ \\
\hline
\end{tabular}

Table 8. Potassium permanganate content and external visual color score of intact and ground alumina beads impregnated with potassium permanganate during exposure to ethylene. Each value is the mean of three replications.

\begin{tabular}{lcc}
\hline Color & \multicolumn{2}{c}{$\mathrm{KMnO}_{4}(\mathrm{~g} / 100 \mathrm{~g})$} \\
\cline { 2 - 3 } score & Intact bead & Powder \\
\hline 5 & 3.7 & 3.7 \\
4 & 3.6 & 2.3 \\
3 & 3.6 & 2.0 \\
2 & 3.4 & 1.2 \\
1.5 & 3.3 & \\
1 & 2.6 & 0.8 \\
\hline
\end{tabular}

Table 9. Correlation coefficient of change in Hunterlab color parameters with potassium permanganate content of intact and powdered alumina beads during exposure to ethylene. Each correlation was calculated from 10 pairs of values.

\begin{tabular}{lcc}
\hline Hunterlab & \multicolumn{2}{c}{ Correlation coefficient, $\mathrm{r}$} \\
\cline { 2 - 3 } parameter & Intact bead & Powdered bead \\
\hline $\mathrm{L}$ & $0.71^{*}$ & $0.83^{* *}$ \\
$\mathrm{a}$ & $-0.74^{*}$ & $-0.95^{* * *}$ \\
$\mathrm{~b}$ & $0.70^{*}$ & $0.93^{* * *}$ \\
$\mathrm{C}$ & $-0.57^{\text {Ns }}$ & $-0.92^{* * *}$ \\
$\Delta \mathrm{E}$ & $0.74^{*}$ & $0.90^{* * *}$ \\
\hline
\end{tabular}

Ns, ,***,***Nonsignificant or significant correlation at $P<0.05,0.01$, or 0.001 , respectively.

seem to be important since the amount of ethylene removed from the atmosphere was found to increase as the amount of potassium permanganate in the chamber increased. The level of potassium permanganate in an alumina absorbent, however, was dependent on the method of preparation. The common laboratory practice of dipping beads in a saturated solution of potassium permanganate at $20{ }^{\circ} \mathrm{C}$ resulted in an absorbent concentration of up to $2 \mathrm{~g} / 100 \mathrm{~g}$, a level attained after dipping for a relatively long period of about $2 \mathrm{~h}$ or after four sequential 3 min dips. The concentration of potassium permanganate was enhanced to about $4 \mathrm{~g} / 100 \mathrm{~g}$ by dipping for $1 \mathrm{~h}$ in a saturated solution at $65^{\circ} \mathrm{C}$ without any evident oxidation as was apparent with dipping at $90{ }^{\circ} \mathrm{C}$. Use of commercial alumina absorbents would seem to also need the level of potassium permanganate to be determined as the products tested showed a wide range of concentrations from 2.7 to $6.0 \mathrm{~g} / 100 \mathrm{~g}$. The values indicate that commercial products are mostly prepared by dipping in solutions at elevated temperatures.

The increase in ethylene absorption was related logarithmically to the weight of absorbent, and hence the amount to potassium permanganate present. Thus, increasing the efficiency of ethylene absorption requires proportionally more potassium permanganate to be present. Under the flow-through system conditions used in this study, the weight of absorbent containing $4 \mathrm{~g} / 100 \mathrm{~g}$ of potassium permanganate required to remove $30 \%, 60 \%$, and $90 \%$ of the ethylene in the flowing system was 1,5 , and $50 \mathrm{~g}$, respectively. These levels of ethylene removal were achieved when the RH of the atmosphere was $70 \%$. The efficiency of ethylene absorption, however, decreased substantially at increasing RH. The RH encountered in horticultural packages is normally $90 \%$ or higher, and ethylene absorption at $90 \% \mathrm{RH}$ was $50 \%$ less efficient than at $70 \% \mathrm{RH}$ as evidenced by the 5.4 and $3.5 \mathrm{~h}$, respectively, taken for $1 \mathrm{~g}$ of absorbent to remove $90 \%$ of the ethylene from the closed system. Translating this finding to the flow-through system suggests that $75 \mathrm{~g}$ of absorbent would be required to remove $90 \%$ of the ethylene from an atmosphere at $90 \% \mathrm{RH}$.

The flow-through system involved the passage of ethylene at $14 \mu \mathrm{L} \cdot \mathrm{h}^{-1}$ through the container. Removal of $90 \%$ of the ethylene by $75 \mathrm{~g}$ of absorbent thus equates to oxidation of $12.6 \mu \mathrm{L} \cdot \mathrm{h}^{-1}$. The rate of production of ethylene by horticultural produce varies widely with non-climacteric produce generally generating ethylene at $<1 \mu \mathrm{L} \cdot \mathrm{kg}^{-1} \cdot \mathrm{h}^{-1}$ at $20^{\circ} \mathrm{C}$ while preclimacteric climacteric fruit often generate ethylene at $1-10 \mu \mathrm{L} \cdot \mathrm{kg}^{-1} \cdot \mathrm{h}^{-1}$ (Kader, 1980). This means that for produce held at $20{ }^{\circ} \mathrm{C}$ in an atmosphere of $90 \%$ $\mathrm{RH}$ and generating ethylene at $1 \mu \mathrm{L} \cdot \mathrm{kg}^{-1} \cdot \mathrm{h}^{-1}, 6 \mathrm{~g}$ of absorbent is required per $1 \mathrm{~kg}$ of produce to reduce the ethylene concentration by $90 \%$, whereas $60 \mathrm{~g}$ of absorbent per $\mathrm{kg}$ of produce is required when ethylene is generated at $10 \mu \mathrm{L} \cdot \mathrm{kg}^{-1} \cdot \mathrm{h}^{-1}$. The use of a potassium permanganate absorbent would thus appear to be a feasible addition to packages of produce that have a low level of ethylene production. Suitability for a $20-\mathrm{kg}$ package of produce generating ethylene at $10 \mu \mathrm{L} \cdot \mathrm{kg}^{-1} \cdot \mathrm{h}^{-1}$ is questionable as $1.2 \mathrm{~kg}$ of absorbent would be required.

The initial efficiency of ethylene removal, however, could only be maintained for $\approx 24 \mathrm{~h}$ after which time ethylene removal declined linearly and after $14 \mathrm{~d}$ in air of $70 \%$ RH only $10 \%$ of the incoming ethylene was being removed. Thus, the amount of absorbent to be added to a particular produce needs to take into account the desired postharvest life as well as the rate of ethylene production. This further diminishes the efficacy of potassium permanganate for long storage of high ethylene-generating produce. The amount of potassium permanganate remaining in the alumina beads after the $14 \mathrm{~d}$ was found to be $44 \%$, close to half the original amount. Thus, loss of efficacy appears not to be due to a lack of potassium permanganate. The initial high rate probably occurs through the oxidation of potassium permanganate on the outer parts of the bead, but under the relatively high $\mathrm{RH}$ conditions, ethylene may not be able to adequately penetrate to the inner parts of the bead, hence the rate of removal slows down. A carrier with a higher permeability to ethylene in high $\mathrm{RH}$ conditions would presumably reduce this deficiency. If the end of the useful life of a potassium permanganate absorbent is considered to be when $50 \%$ has been oxidized, instrumental color measurement can readily determine this stage. However, visual inspection of crushed beads can be an effective quick test with $60 \%$ retention of the original purple color being the end point. A standard color paper strip could be readily generated to conduct such evaluations. Inspection of intact beads is not a reliable guide to the degree of oxidation of potassium permanganate.

\section{Literature Cited}

Abeles, F,B,, P.W. Morgan, and M.E. Saltveit. 1992. Ethylene in plant biology. $2^{\text {nd }}$ ed. Academic Press, New York,.

Dean, J.A. 1995. Analytical chemistry handbook, McGraw-Hill, 
New York.

Esguerra, E.B., J.R. Mendoza, and E.B. Pantastico. 1978. Regulation of fruit ripening. II. Use of perlite- $\mathrm{KMnO}_{4}$ insert as an ethylene absorbent. Philippine J. Sci. 107:23-31.

Forsyth, F.R., C.A. Eaves, and C.L. Lockhard. 1967. Controlling ethylene levels in the atmosphere of small containers of apples. Can. J. Plant Sci. 47:717-718.

Hatton, T.T. and W.F. Reeder. 1972. Quality of 'Lula' avocados stored in controlled atmospheres with or without ethylene. J. Amer. Soc. Hort. Sci. 97:339-343.

Jayamaran, K.S. and P.S. Raju. 1992. Development and evaluation of a permanganate-based ethylene scrubber for extending the shelf life of fresh fruits and vegetables. J. Food Sci. Technol. 29:77-83.

Kader, A.A. 1980. Prevention of ripening in fruits by use of controlled atmospheres. Food Technol. (March):51-54.

Kader,A.A. 1985. Ethylene-induced senescence and physiological disorders in harvested horticultural crops. HortScience 20:54-57.

Kavanagh, E.E. and N.L. Wade. 1987. Role of the carrier in the removal of ethylene by permanganate from storage atmospheres. ASEAN Food J. 3:128-134.

Kim, G.H. and R.B.H. Wills. 1995. Effect of ethylene on storage life of lettuce. J. Sci. Food Agr. 69:197-201.

Lide, D.R. 1994. CRC Handbook of chemistry and physics. CRC Press, London.

Lidster, P.D., R.A. Lawrence, G.D. Blanpied, and K.B McRae. 1985. Laboratory evaluation of potassium permanganate for ethylene removal from CA apple storage. Trans. Amer. Soc. Agr. Eng. (331-334):339.
Oh, S.Y., S.S. Shin, C.C. Kim, and Y.J. Lim. 1996. Effect of packaging films and freshness keeping agents on fruit quality of 'Yumyung' peaches during MA storage. J. Korean Soc. Hort. Sci. 37:781-786.

Peacock, B.C. 1972. Role of ethylene in the initiation of fruit ripening. Queensland J. Agr. Anim. Sci. (29):137-145.

Picon,A., J.M. Martinez-Javega, J.C Cuquerella, M.A.D. Rio, and P. Navaroo. 1993. Effects of precooling, packaging film, modified atmosphere and ethylene absorber on the quality of refrigerated Chandler and Douglas strawberries. Food Chem. 48:189-193.

Scott, K.J., J. Guigni, and W. Bailey. 1984. The use of polyethylene bags and ethylene absorbent to extend the life of kiwifruit (Actinidia chinensis Planch) during cool storage. J. Hort. Sci. 50:563-566.

Scott, K.J., W.B. McGlasson, and E.A. Roberts. 1970. Potassium permanganate as an ethylene absorbent in polyethylene bags to delay ripening of bananas during storage. Austral. J. Expt. Agr. Animal Husb. 10: 237-240

Wild, B.L., W.B. McGlasson, and T.H. Lee. 1976. Effect of reduced ethylene levels in storage atmospheres on lemon keeping quality. HortScience 11:114-115.

Wills, R.B.H. and G.H. Kim. 1995. Effect of ethylene on postharvest life of strawberries. Postharvest Biol. Technol. 6:249-255.

Wills, R.B.H., V.V.V. Ku, D. Shohet, and G.H. Kim. 1999. Importance of low ethylene levels to delay senescence of non-climacteric fruit and vegetables. Austral. J. Expt. Agr. 39:221-22.

Wills, R.B.H., M.A. Warton, D.M.D.N. Mussa, and L.P. Chew. 2001. Ripening of climacteric fruits initiated at low ethylene levels. Austral. J. Expt. Agr. 41:89-92. 